\title{
Üniversite Öğrencilerinde Olumlu Düşünme Becerisinin Kişilerarası İletişim Becerisi ile İlişkisi
}

\section{The Relationship Between Positive Thinking skills and Interpersonal Communication Skills in University Students}

\author{
Şule Karadağ a,* \\ aDr. Öğr. Üyesi, Giresun Üniversitesi, Tirebolu İletişim Fakültesi, Halkla İlişkiler ve Tanıtım Bölümü Tirebolu/Giresun/Türkiye \\ ORCID: 0000-0002-5082-3449
}

\begin{tabular}{l} 
MAKALE BİLGİSİ \\
\hline Makale Geçmişi: \\
Başvuru tarihi: 01 Şubat 2019 \\
Düzeltme tarihi: 03 Temmuz 2019 \\
Kabul tarihi: 29 Temmuz 2019 \\
\hline Anahtar Kelimeler: \\
İletişim \\
Olumlu Düşünme \\
Kişilerarası İletişim \\
Öğrenciler
\end{tabular}

\section{A R T I C L E I N F O}

Article history:

Received 01 February 2019

Received in revised 03 July 2019

Accepted 29 July 2019

\section{Keywords:}

Communication

Positive Thinking

İnterpersonal Communication

Students
ÖZ

$\mathrm{Bu}$ çalışma üniversite öğrencilerinin olumlu düşünme becerileri ile kişilerarası iletişim becerileri arasındaki ilişkiyi ortaya koymak amacı ile planlanmıştır. Kesitsel ve değişkenler arasındaki ilişkileri belirlemek amacıyla ilişki arayıcı - tanımlayıcıtasarım kullanılmıştır. Çalışmada olumlu düşünme becerileri ölçeği ile kişilerarası iletişim becerisi ölçekleri kullanılmıştır. Analizleri sonucundakatılımcıların \%67,6'sı $(n=275)$ kadın, \%32,4'ü $(n=132)$ erkektir ve olumlu düşünme becerisi toplam puan $\bar{x}=15,36 \pm 4,44$, kişilerarası iletişim becerisi toplam puan $\bar{x}=99,10 \pm 12,66$ olarak tespit edilmiştir. Çalışmanın sonucunda, olumlu düşünme becerisi ile cinsiyet arasında anlamlı ilişki görülmüştür $(\mathrm{p}<0.05)$. Aynı şekilde olumlu düşünme becerileri ile kişilerarası iletişim toplam puan ve alt faktörleri (iletişim ilkeleri ve temel becerileri, kendini ifade etme, etkin dinleme ve sözel olmayan iletişim ve iletişim kurmaya isteklilik) arasında da anlamlı bir ilişki saptanmıştır.

\section{A B S T R A C T}

This study was planned to reveal the relationship between positive thinking skills and interpersonal communication skills of university students. Relational-descriptive design was used to determine cross-sectional relationships and relationships between variables.

As a result of the data analyses, \%67,6 $(n=275)$ of the participants were female and $\% 32,4(n=132)$ were maleand the total score of positive thinking skills of the participants was $\bar{x}=15,36 \pm 4,44$ and the interpersonal communication skill total score was determined to be $\bar{x}=99,10 \pm 12,66$. As a result of the study, positive thinking scores significantly differed based on gender $(\mathrm{p}<0.05)$. In the same way, there was a significant relationship between positive thinking skills and the total score and sub-factors of interpersonal communication (communication principles and basic skills, selfexpression, effective listening and non-verbal communication and willingness to communicate).

\section{Giriş}

Bireylerin toplum içerisinde kendilerine yer edinebilmeleri, toplumda belli bir statüye ulaşabilmeleri için sosyal becerilere sahip olmaları gerekir. Sosyal açıdan yeterlilik davranışı, belirli bir kişilerarası şartlarda çok iyi olarak algılanan etkileşim davranışını kastetmektedir (Allen, Preiss, Gayle\&Burrell, 2001). Bir başka ifade ile olumsuz tepkiler yerine olumlu tepkileri getirecek, çevre ile etkileşim içeren ve etki bırakan, sosyal açıdan kabul edilebilir, hedefe yönelik, şartlara göre değişebilen, gözlenebilir ya da gözlenemeyen öğrenilebilir davranışlardır (Yüksel, 2016:38). Sosyal beceriler, psikolojik olarak kendini iyi hissetme ile pozitif ilişkiler arasında olumlu ve güçlü ilişki olduğu

\footnotetext{
*Sorumlu yazar/Corresponding author

e-posta: sule.karadag@giresun.edu.tr
} 
görülmektedir(Segrin \& Taylor, 2007:643). Ailelerinden ayrılarak yüksekokula gelen öğrenciler arasında yapılan bir çalışma da sosyal becerileri düşük olan öğrencilerin, dönem sonunda yüksek olanlara nazaran psiko-sosyal problemlerin gelişimine karşın daha savunmasız oldukları görülmüştür. Sosyal becerileri düşük bireyler depresyon, yalnızlık, sosyal kaygı gibi problemlerle daha fazla karşı karşıya kalmaktadırlar (Segrin\& Flora, 2000). Sosyal beceri davranışı öğrenilebilir davranışlardır. Yapılan bir çalışmaya göre (Yüksel, 2016:45) sosyal beceri eğitimi verilen öğrencilerin verilmeyen öğrencilere göre beceri düzeyleri daha yüksek çıkmıştır.

Sosyal beceri, sosyal yeterlilik, kişilerarası beceri ya da iletişim yeterliliği olarak anılmaktadır (Spitzberg\&Dillard, 2002: 89). İletişim becerileri, kişilerarası problem çözme becerisi ve sosyal öz yeterlilik arasında anlamlı bir ilişki vardır ve iletişim becerisi ile problem çözme becerisi sosyal öz yeterlilikte önemli bir belirleyicidir. Problem çözme, etkili bir iletişim ile ancak başarıya ulaşabilir ve bu bütün problem çözme yaklaşımlarının genel özelliğidir (Erozkan, 2013:742). İletişim, her canlının sahip olduğu, insanların ise kendini dünyaya açtığı bir kapı niteliğindedir. Bu nedenle çevresi ile sürekli etkileşim halinde sosyal bir varlık olan insan için iletişimin rolü yadsınamaz. Öğrencilerin, çalışanların, yöneticilerin, çiftlerin hem sosyal hayatlarında hem de iş hayatlarında kişilerarası ilişkilerde başarıya ulaşmalarının temel taşı etkili iletişim becerileri ile mümkündür. İlişki doyumunda, bağlanma şekilleri ve çeşitli problem çözme becerileri gibi, iletişim becerileri de bağlantılıdır (Ĕ̆eci\&Gençöz, 2006:388).

Birey, ister kendi başına isterse başkalarıyla bir arada yaşasın, mutlaka bir iletişim sürecinin içindedir. $\mathrm{Bu}$ süreç, kendi kendine iç iletişim, başkalarıyla yaptığı kişilerarası iletişimden kitle iletişime kadar bir yelpazedir. İletişim kurmak insanın doğasında bulunan bir şekilde öğrenilen bir süreçtir. İletişim kavramını İnceoğlu (2011:200), doğrusal veya çizgisel bir süreç şeklinde değil aksine fazlasıyla karmaşık bir etkileşim alanı olarak ele almaktadır. Fakat her ne olursa olsun iletişimin temelinde kaynağın hedefle ilgili beklentilerinin bulunduğunu belirtmektedir. Bununla birlikte kaynağın içinde bulunduğu ruh hali de kişiler arası iletişime etki eden etmenlerden biridir. Nelson (2016:1538) tarafindan yapılan bir çalışma da olumlu ruh halinin sosyal yanlış anlamaları önleyebileceği ve farklı kişilerle tarafsız bir ruh halinden çok daha etkili bir şekilde ilişki kurmasını sağlayabileceğini belirtmiştir.

Olumlu duygular ve olumsuz duygular kişilerarası ilişkilerde önemli bir role sahiptir (Lyubomirsky\& Sin, 2009). Hayata pozitif bakış açısı, ortaya çıkan negatif durumlarla baş etmeyi kolaylaştırdığı gibi bireyler arası ilişkilere etki edecek ölçüde önemlidir. Olumlu duygulanımlara sahip bireyler ile olmayanlarında mizaçları farklılık gösterir. Olumlu duygulanımları yüksek olan kişiler genellikle dişa dönük kişilik özelliklerine sahip olan bireylerdir ve bu kişiler daha kolay sosyal etkileşimde bulunurlar, dişa dönük kișilik özelliğine sahip kişilerin iletişime gönüllülük oranları da yüksektir (Karadağ \& Kaya, 2018:417). Pozitif duygulara sahip bireyler, daha kolay sosyal etkileşimde bulunurlar ve diğer kişilere göre grup içerisinde daha avantajlıdırlar. Pozitif psikoloji ise bu noktada hayatın akışı içerisinde ortaya çıkan olumsuzlukları düzeltmek ve pozitif özellikler ortaya çıkarmayı amaçlamaktadır. Bireysel düzeyde; pozitif bireysel özellikler, sevgi ve yetenek kapasitesi, cesaret, kişilerarası beceri, estetik, hassasiyet, yaratıcılık, yüksek yetenek ve bilgelikle ilgilidir (Seligman\&Csikszebtmihalyi, 2000: 5).

Pozitif düşünme olayların aydınlık tarafını görme becerisidir ve kişileri daha yaratıcı ve yapıcı yapar (Naseem\&Khalid, 2010:42). Olaylara olumlu olarak yaklaşma, olumlu düşüncelerle değerlendirme şekli bireylerin günlük hayatlarının kalitesine de etki etmektedir. Pozitif düşünme pozitif duygular, iyimserlik, umut, sevinç ve mutlulukla da bağlantılıdır (Naseem\&Khalid, 2010:42). İyimserlik yaşam kalitesini ve ilişkileri etkileyen etmenlerdendir. İyimser özelliklere sahip bireyler güzel olayların olacağı beklentisini her zaman korurlar ve bakış açıları ve olaylara yaklaşımları da bu yönde olur. Bu tür beklenti içerisindeki bireyler olmayanlara nazaran sıkıntılı durumlara ya da zorluklara daha kolay uyabilen bireylerdir (Carver, Scheier\&Segerstrom, 2010: 886).

Pozitif düşünme, araştırmacılar tarafından farklı açılardan ele alınan bir yaklaşımdır. Genel olarak birçok görüş, pozitif düşünmenin, bireyin geleceği için pozitif beklentilerini içerdiği ve bu beklentilerin de davranışa yansıdığı üzerinde birleşir. Pozitif düşünmenin etkilerini gören insanlar süreç ne kadar yavaş ya da zor olursa olsun bu davranışa devam etmektedirler. Sonuçlara hemen ulaşamayan kişiler çabalarından vazgeçip, geri çekilme eğilimi gösterirler. Bu nedenle insanların beklentileri onlara iki tercih sunar, çabalamaya devam etmek ya da vazgeçmek (Scheier\& Carver, 1993: 26). Yapılan çalışmalar göstermektedir ki; olumlu düşünme becerileri bireylerin ruhsal sağlıklarını ve kendilerine saygılarını artırmakta, örgütsel bağlılığ1 artırmaya etki etmekte, stres faktörleri ile baş etmeyi kolaylaştırmaktadır (Shokhmgar, 2016:210, Shabani, Pour, Morovat\&Khaledian, 2016:253, FernandezGonzalez, Gonzalez-Hernandez\&Trianes-Torres, 2015:122). Tsivilskaya\&Artemyeva (2016:203)'nın yapmış olduğu çalışmada ise; katılımcıların yarıdan fazlası keyifle mizah kullanan iyimser öğrencilerdir ve bu özellik kişilerarası ilişkilerin sürdürülmesinde stresli ortamlarda tansiyonu düşürmek için önemli araçlardan biridir.

İletişim becerisi bireylerin hayatının her alanına etki eden bir unsurdur. Aile ilişskilerinde, okul ya da iş hayatında, arkadaşlıklarında etkili iletişim becerilerine sahip olan bireyler ortam içerisinde her zaman bir adım öne çıkmaktadır. İletişim becerileri doğru kullanabilen bireyler aynı zamanda kendini çok daha kolay ifade edebilmekte ve bu durum psikolojik anlamda bireylere bir doyum sağlamaktadır. Üniversite öğrencileri üzerinde yapılan bir çalışma da arkadaşlık ilişkileri olumlu ve sakin öğrenciler ile sözel kavga yaşan öğrencilerin iletişim beceri puanları ile fiziksel kavga yaşayan öğrencilerin puanlarına göre daha yüksektir Erigüç, Şener \&Eriç, 2013:55).

Hayata olumlu bakış açışı, iyimserlik, kişilerin ilişkilerinde de etkili bir unsurdur. İyimser öğrenciler yeterli özgüvene sahip, kendilerini bir birey olarak kabul eden, kendilerini pozitif bir taşıyıcı olarak kabul etmeye meyilli, sosyal olarak beğenilen özelliklerde ve yüksek oranda iradeye sahiptirler (Tsivilskaya\&Artemyeva, 2016:203). Nitekim yapılan çalışmalar da göstermektedir ki; iletişim becerileri ve duygusal zeka alt boyutlarından duyguların pozitif kullanımı (iyimserlik) arasında ilişki söz konusudur 
(Taşliyan, Hırlak, Harbalıŏglu, 2015,Büyükbeşe, Direkçi, Erşahan, 2017, Pelit, Karaçor, Kılıç, 2018).

İletişim becerisi duygusal zekanın belirleyici etkenlerinden biridir ve iki şekilde açıklanabilir. Bunlardan biri kendini açık ve net ifade edebilme bir diğeri ise dikkatli dinleme ve söylenenleri net olarak anlayabilmedir (Çetinkaya \& Alparslan, 2011:366). Olumlu düşünme ise De Bono'nun "Altı Şapkalı düşünme" biçimlerinde de yer verdiği sarı şapkayı ifade etmektedir. Sarı şapka iyimser, umutlu ve olumlu düşünmeyi ifade etmektedir (Güneş, 2012:134). İyimser ve olumlu düşünme becerisine sahip kişi yapııı ve üreticidir. Bu tür düşünme biçimleri aynı zamanda işbirliği gerektirdiği için bireylerin etkili bir kişilerarası iletişim becerisine sahip olduğu düşünülebilir.

Olumlu düşünme becerisinin, kişilerarası ilişkileri pozitif yönde etkileyeceği ve bu becerilere sahip bireylerin kişilerarası iletişim becerilerinin yüksek olacağı düşünülmektedir. $\mathrm{Bu}$ çalışmanın amacı, tüm bu bilgiler çerçevesinde pozitif düşünme becerisinin kişilerarası iletişime etkilerini ortaya koymaktır.

\section{Yöntem ve Uygulama}

\subsection{Tasarım}

Kesitsel ve değişkenler arasındaki ilişkileri belirlemek amacıyla ilişki arayıcı - tanımlayıcıtasarım kullanılmıştır.

\subsection{Evren ve Örneklem}

Araştırmanın evreninin Bozok Üniversitesinde eğitimöğretime devam eden öğrenciler oluşturmaktadır. Çalışmanın örneklem sayısının hesaplanmasında ilişki arayan, regresyon analizi ya da korelasyon analizi uygulanan çalışmalar için hazırlanmış hesaplama tekniklerinden yararlanılmıştır (Cohen, J.,Cohen, West \&Aiken, 2003). Çalışmadaki bağımsız değişken sayısı (6) dikkate alınarak; 0.05 etki büyüklüğü,0,95 güç düzeyi ve 0.05 önemlilik düzeyinde gerekli örneklem büyüklüğü 425 olarak bulunmuştur.

\subsection{Veri Toplama Tekniği ve Araçlar}

Veriler katılımcılardan anket formu, olumlu düşünme becerisi ve kişilerarası iletişim becerisi ölçeklerinin uygulanmasıyla elde edilmiştir.

\section{Olumlu Düşünme Becerisi Ölçeği}

Bekhet\&Zauszniewski (2013)tarafindan geliştirilen olumlu düşünme becerileri ölçeği, Akın, Uysal \& Akın (2015) tarafindan Türkçe'ye çevrilerek geçerlilik, güvenilirlik çalışması gerçekleştirilmiştir. Yapılan doğrulayıcı faktör analizi sonucunda, 8 maddeden ve tek boyuttan oluşan modelin iyi uyum verdiği bulunmuştur $\left(\mathrm{x}^{2}=25.66, \mathrm{sd}=19\right.$, $\mathrm{RMSEA}=.035, \mathrm{NFI}=.99, \mathrm{NNFI}=.99, \mathrm{IFI}=1.00, \mathrm{RFI}=.98$, $\mathrm{CFI}=1.00, \mathrm{GFI}=.98, \mathrm{AGFI}=.96, \mathrm{SRMR}=.027)$. Ölçeğin iç tutarlılık güvenirlik katsayısı .87 olarak tespit edilmiştir (Akın, A., Uysal, R., \& Akın, Ü., 2015). Ölçeğin düzeltilmiş madde toplam korelasyonları ise .54 ile .68 arasında sıralanmaktadır. Toplam sekiz sorudan oluşan ölçekte; her bir soru 0 (asla), 1 (Biraz), 2 (Çoğunlukla), 3 (Her zaman) şeklinde puanlanmaktadır. Ölçekte ters kodlanan madde bulunmamakla birlikte puanın yüksek olması yüksek düzeyde olumlu düşünme becerisini olduğunu işaret etmektedir.

\section{Kiş̧ilerarası İletişim Becerileri Ölçeği}

Korkut-Owen\& Bugay (2014) tarafından geliştirilen ölçek, 25 maddeden ve dört faktörlü bir yapıdan oluşmaktadır. Belirtilen alt faktörler; iletişim ilkeleri ve temel becerileri $(1,3,6,13,14,16,21,23,24,25)$, kendini ifade etme $(2,5$, $17,20)$, etkin dinleme ve sözel olmayan iletişim $(10,11,12$, $18,19,22)$, iletişim kurmaya isteklilik $(4,7,8,9,14)$ şeklindedir. Ölçeğin Cronbach alfa katsayısı .88 olarak hesaplanmıştır. Ölçeğin alt faktörlere ilişkin iç tutarlılık katsayıları ise; İITB .79, KİE .72, EDSOİ .64, ve İKİ .71 olarak tespit edilmiştir. Elde edilen değerler neticesinde ölçeğin güvenilirlik düzeyinin yeterli olduğu ve uygulanabilir olduğu görülmüştür (Korkut-Owen\& Bugay (2014).

\subsection{Verilerin Toplanmas1}

Araştırmanın verileri Mart 2018 ve Ekim 2018 tarihleri arasında, birebir görüşmeler ile formların doldurulması yoluyla elde edilmiştir.

\subsection{Araştırmanın Değişkenleri}

Araştırmanın değişkenlerini kişilerarası iletişim becerileri puan düzeyi (bağımlı değişken) ile olumlu düşünme becerileri puan düzeyi ve öğrencilerin sosyo-demografik özellikleri (bağımsız değişkenler) oluşturmaktadır.

\subsection{Araştırma Soruları}

Çalışmadaki temel araştırma soruları aşağıdaki gibi belirlenmiştir.

- Olumlu düşünme becerileri puan düzeyi nedir?

- Kişilerarası iletişim becerileri puan düzeyi nedir?

- Sosyo-demografik özellikler olumlu düşünme becerilerini ve kişilerarası iletişim becerilerini etkiler mi?

- Öğrencinin iletişim konularını içeren dersler alması kişilerarası iletişim becerilerini etkiler mi?

- Olumlu düşünme becerileri ve kişilerarası iletişim becerileri arasında bir ilişki var mıdır?

\subsection{Araştırma Etiği}

Araştırma için Bozok Üniversitesi Bilimsel araştırmalar ve yayın etiği kurulundan etik kurul izni alınmıştır. Ayrıca katılımcıların hepsinden araştırmaya katılıp katılmayacaklarını yönünde sözlü onam alınarak uygulama gerçekleştirilmiştir.

\subsection{Araştırma Analizi}

Verilerin toplanmasının ardından, veri girişine uygun olan formlar (boş birakılan soru bulunan formlar analize dahil edilmemiştir) istatistik programına aktarılmıştır. Programa aktarılan veriler üzerinde değişkenler arasındaki ilişkileri ortaya koymak amaciyla t-test, anova ve korelasyon analizi yapılmıştır. 


\section{Bulgular}

Araştırmaya katılan öğrencilerin olumlu düşünme becerileri, kişilerarası iletişim becerileri ölçekleri ve sosyodemografik bilgileri içeren anket formlarına vermiş oldukları yanıtlar incelenmiştir. Elde edilen veriler istatistik analizi programı gerçekleştirilmiş, olumlu düşünme becerileri ölçeği ve kişilerarası iletişim becerileri ölçeği arasındaki ilişkiyi ortaya koymak amacıyla pearson test uygulanmış, ikili grupların ölçekler ile arasındaki ilişkileri belirlemek amacıyla independent t-test uygulanmıştır.

Tablo 1. Katılımcıların Sosyo-demografik Özellikleri

\begin{tabular}{llcc}
\hline \multirow{2}{*}{ Cinsiyet } & & Sayı & \% \\
\hline \multirow{2}{*}{ Ekonomik Durum } & Kadın & 275 & 67,6 \\
\cline { 2 - 4 } & Erkek & 132 & 32,4 \\
\hline \multirow{2}{*}{ İletişim Dersi Alma Durumu } & Iyi & 123 & 30,2 \\
\cline { 2 - 4 } & Orta & 269 & 66,1 \\
\cline { 2 - 4 } & Kötü & 11 & 2,7 \\
\cline { 2 - 4 } Toplam & Evet & 131 & 32,2 \\
\cline { 2 - 4 } & Hayır & 276 & 67,8 \\
\hline
\end{tabular}

Ankete katılan öğrencilerin sosyo-demografik özellikleri ve iletişim dersi alma durumuna tablo 1'de verilmiştir. Buna göre katılımcıların \%67,6'sını kadın, \%32,4'ünü erkekler oluşturmakta, ekonomik duruma bakıldığında ise \%30,2'sinin iyi, \%66,1'inin orta, \%2,7'sinin kötü olduğu görülmektedir. Bununla birlikte katılımcılara sorulan iletişim dersi alıp almadıkları yönündeki soruya verilen cevapların \%32,2'sini evet \%67,8'ini hayır cevapları oluşturmaktadır.

Tablo 2. Olumlu Düşünme Becerileri Ölçeği ile Kişilerarası İletişim Becerileri Ölçeği Toplam Puan ve Alt Faktörler Puan Durumu

\begin{tabular}{|c|c|c|c|c|}
\hline Ölçek Toplam Puanları & Sayı & Min. & Max. & $\overline{\mathbf{x}} \pm \mathrm{SD}$ \\
\hline $\begin{array}{l}\text { Olumlu Düşünme } \\
\text { Becerileri } \\
\text { Ölçeği Toplam } \\
\text { Puanı(OTOP) }\end{array}$ & 407 &, 00 & 24,00 & $15,36 \pm 4,44$ \\
\hline $\begin{array}{l}\text { Kişilerarası İletişim } \\
\text { Becerileri } \\
\text { Ölçeği Toplam } \\
\text { Puanı(KİÖTOP) }\end{array}$ & 407 & 40,00 & 126,00 & $99,10 \pm 12,66$ \\
\hline $\begin{array}{l}\text { İletişim İlkeleri ve Temel } \\
\text { Becerileri (İITB) }\end{array}$ & 407 & 6,00 & 30,00 & $24,07 \pm 3,60$ \\
\hline Kendini İfade Etme (KİE) & 407 & 4,00 & 20,00 & $16,11 \pm 2,72$ \\
\hline $\begin{array}{l}\text { Etkin Dinleme ve Sözel } \\
\text { Olmayan İletişim(EDSOI) }\end{array}$ & 407 & 6,00 & 30,00 & $24,07 \pm 3,60$ \\
\hline $\begin{array}{l}\text { İletişim Kurmaya } \\
\text { İsteklilik(İKİ) }\end{array}$ & 407 & 6,00 & 50,00 & $18,96 \pm 3,77$ \\
\hline
\end{tabular}

Verilerin analizi sonucunda katılımcıların olumlu düşünme becerileri(ODB) ölçeği toplam puanı ortalaması $\overline{\mathrm{x}}=15,36 \pm 4,44$ olarak bulunmuştur. Kişilerarası iletişim becerileri ölçeği toplam puan ortalaması ise $\bar{x}=99,10 \pm 12,66$ olarak tespit edilmiştir. Her iki ölçeğin puan durumu ortalamanın üzerini göstermektedir. $\mathrm{Bu}$ durum katılımcıların ortalamanın biraz üzerinde olumlu düşünme becerisine ve kişilerarası iletişim becerisine sahip olduklarını göstermektedir (Tablo 2).
Tablo 3. Olumlu Düșünme Becerileri Ölçeği ve Kișilerarası İletişim Becerileri Ölçeği Puan Düzeyleri ile Sosyo-Demografik Özellikler İlișki Durumu

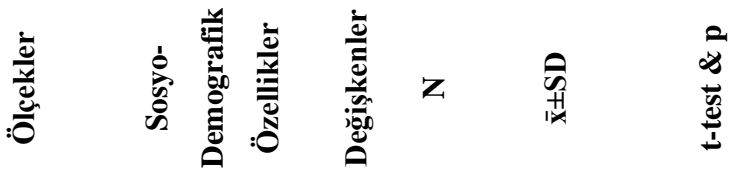

\begin{tabular}{|c|c|c|c|c|c|}
\hline \multirow{3}{*}{$\begin{array}{l}\text { Olumlu } \\
\text { Düşünme } \\
\text { Becerileri } \\
\text { Puanı(OTO } \\
\text { P) }\end{array}$} & Cinsiyet & $\begin{array}{l}\text { Kad1 } \\
\mathrm{n} \\
\text { Erke } \\
\mathrm{k}\end{array}$ & $\begin{array}{l}275 \\
132\end{array}$ & $\begin{array}{l}14,89 \pm 4,59 \\
16,33 \pm 3,98\end{array}$ & $\begin{array}{l}t=-3,23 \\
p<, 001\end{array}$ \\
\hline & $\begin{array}{l}\text { Ekonomik } \\
\text { Durum }\end{array}$ & $\begin{array}{l}\text { Iyi } \\
\text { Orta } \\
\text { Kötü }\end{array}$ & $\begin{array}{c}123 \\
269 \\
11\end{array}$ & $\begin{array}{l}15,19 \pm 4,82 \\
15,37 \pm 4,30 \\
16,45 \pm 3,69\end{array}$ & $\begin{array}{l}F=, 415 \\
p>, 660\end{array}$ \\
\hline & $\begin{array}{l}\text { İletişim } \\
\text { Dersi } \\
\text { Alma } \\
\text { Durumu }\end{array}$ & $\begin{array}{l}\text { Evet } \\
\text { Hayı } \\
\mathrm{r}\end{array}$ & $\begin{array}{l}131 \\
276\end{array}$ & $\begin{array}{l}15,38 \pm 4,54 \\
15,35 \pm 4,41\end{array}$ & $\begin{array}{l}t=0,79 \\
p>, 937\end{array}$ \\
\hline \multirow{3}{*}{$\begin{array}{l}\text { Kişileraras1 } \\
\text { İletişim } \\
\text { Becerileri } \\
\text { Toplam } \\
\text { Puanı(ITTOP } \\
\text { ) }\end{array}$} & Cinsiyet & $\begin{array}{l}\text { Kad1 } \\
\mathrm{n} \\
\text { Erke } \\
\mathrm{k}\end{array}$ & $\begin{array}{l}275 \\
132\end{array}$ & $\begin{array}{c}98,69 \pm 12,73 \\
99,96 \pm 12,5 \\
1\end{array}$ & $\begin{array}{l}t=-, 957 \\
p>, 340\end{array}$ \\
\hline & $\begin{array}{l}\text { Ekonomik } \\
\text { Durum }\end{array}$ & $\begin{array}{l}\text { İyi } \\
\text { Orta } \\
\text { Kötü }\end{array}$ & $\begin{array}{c}123 \\
269 \\
11\end{array}$ & $\begin{array}{r}98,99 \pm 13,95 \\
99,37 \pm 11,82 \\
96,54 \pm 15,06\end{array}$ & $\begin{array}{l}F=, 288 \\
p>, 750\end{array}$ \\
\hline & $\begin{array}{l}\text { İletişim } \\
\text { Dersi } \\
\text { Alma } \\
\text { Durumu }\end{array}$ & $\begin{array}{l}\text { Evet } \\
\text { Hay1 } \\
\mathrm{r}\end{array}$ & $\begin{array}{l}131 \\
276\end{array}$ & $\begin{array}{l}98,04 \pm 13,56 \\
99,61 \pm 12,20\end{array}$ & $\begin{array}{c}t=-1,123 \\
p>, 262\end{array}$ \\
\hline
\end{tabular}

Ankete katılan bireylerin olumlu düşünme becerileri düzeyi ile cinsiyetleri arasında anlamlı bir ilişki olduğu görülmüştür $(\mathrm{p}<, 001)$. Katılımcıların cinsiyetleri ve olumlu düşünme beceri düzeyleri karşılaştırıldığında erkeklerin $(\bar{x}=16,33)$ olumlu düşünme becerileri düzeyinin kadınlardan $(\overline{\mathrm{x}}=14,89)$ fazla olduğu görülmektedir. Yapılan analizler sonucunda olumlu düşünme becerileri ile ekonomik durum ve iletişim dersi alma durumu arasında anlamlı bir ilişki saptanmamıştır. Kişilerarası iletişim becerileri düzeyleri ile cinsiyet, ekonomik durum ve iletişim dersi alma durumu arasında anlamlı bir fark bulunmamaktadır. (p>,340, p>,750, p>,262, tablo 3).

Tablo 4. Olumlu Düşünme Becerileri Toplam Puanı ile Kişilerarası İletişim Becerileri Toplam Puanı ve Alt Faktörler Arasındaki İlişski Durumu

\begin{tabular}{ccccccc}
\hline & & İTOP & İİTB & KİE & EDSOI & İKI் \\
\hline & $\mathrm{r}$ &, $511^{* *}$ &, $433^{* *}$ &, $423^{* *}$ &, $370^{* *}$ &, $386^{*}$ \\
OTOP & $\mathrm{p}$ & $\mathbf{, 0 0 0}$ & $\mathbf{, 0 0 0}$ & $\mathbf{, 0 0 0}$ & $\mathbf{, 0 0 0}$ & $\mathbf{, 0 0 0}$ \\
& $\mathrm{n}$ & 407 & 407 & 407 & 407 & 407 \\
\hline
\end{tabular}

**. 0.01 düzeyinde korelasyon anlamlıdır.

Katılımcıların olumlu düşünme becerileri ile kişilerarası iletişim becerileri toplam puanı arasında anlamlı bir ilişki olduğu görülmüştür( $\mathrm{p}<, 000)$. Aynı şekilde olumlu düşünme becerileri toplam puan durumu ile kişilerarası iletişim becerileri alt faktörleri, iletişim ilkeleri ve temel becerileri $(p<, 000)$, kendini ifade etme $(p<, 000)$, etkin dinleme ve sözel olmayan iletişim $(p<, 000)$ ve iletişim kurmaya isteklilik arasında da anlamlı bir fark olduğu saptanmıştır (Tablo 4). 


\section{Sonuç}

Olumlu düşünme becerisi hayatın akışı içerisinde bireylere birçok avantaj sağlayabilecek becerilerden biridir. Yapılan birçok çalışma göstermektedir ki; pozitif düşünme becerisi, stresle ve kaygı ile baş etme, problem çözme, mutluluk, akademik performans ve hatta sağlik üzerinde önemli bir etkendir (Scheier\& Carver, 1992: 224, Panahi, Panahi\&Sobhani, 2016:7, Naseem\&Khalid, 2010:53). Pozitif düşünme becerisinin insan hayatında ve davranışlarında bu denli önemli bir role sahip olması, bizde aynı zamanda "Pozitif düşünme becerisi kişilerarası iletişim becerilerinin üzerinde de etkili midir? sorusunu akla getirmiştir. Çalışma bu çerçevede şekillenmiş ve pozitif düşünme becerisi ve kişilerarası iletişim becerisi arasındaki ilişkiyi ortaya koymak amaçlanmıştır.

Kişilik ve öznel mutluluk arasında güçlü bir ilişki vardır, bununla birlikte kişilik ile kişilerarası iletişim biçimleri arasında da bir ilişki söz konusudur (Richard\&Diener, 2009, Leung\& Bond, 2001). Hazar (2006:139) tarafindan yapılan bir çalışmada hoş sohbet, atılgan, liderlik ve oturmuş-dışadönük kişilik özelliklerine sahip kişilerin daha çok kişilerarası iletişim tipi tercih ettiği görülmüştür. Dolayısı ile pozitif düşünme ve kişilerarası iletişim arasında ilişki kaçınılmaz görülmektedir. Yapılan literatür taraması sonucunda olumlu düşünme becerisi be kişilerarası iletişim becerileri arasındaki ilişkiyi ortaya koyan çok fazla çalışmaya rastlanmamıştır.

Çalışmada olumlu düşünme becerisi ile cinsiyet arasında anlamlı bir ilişki olduğu ve erkeklerin olumlu düşünme becerisinin kadınlara oranla biraz daha yüksek olduğu görülmektedir. Benzer bir çalışma da aynı şekilde cinsiyet ve duygusal zekâ $(p=0,039<0,05)$ arasında ilişki tespit edilirken, iletişim becerisi ve cinsiyet $(p=0,337>p)$ arasında bir ilişki saptanmamıştır(Taşlıyan, Hırlak, Harbalığlu, 2015: 54). Bununla birlikte olumlu düşünme becerisi ile ekonomik durum ve iletişim dersi alma durumu arasında herhangi bir ilişki söz konusu değildir(Tablo 3). Aynı şekilde kişilerarası iletişim becerisi ile cinsiyet, ekonomik durum ve iletişim dersi alma durumu arasında bir farklılık saptanmamıştır. Bir başka çalışmada ise cinsiyet ve iletişim becerisi arasında anlamlı fark görülürken, ekonomik durum ile iletişim becerisi arasında bu çalışmada da olduğu gibi bir fark tespit edilmemiştir(Erigüç, Şener \&Eriç, 2013:58). Bu sonuçlara bakılarak genel bir sonuca ulaşmak mümkün değildir.

Hayata pozitif bakma, olumlu düşünme becerisi bireylerin sosyal hayatlarına etki eden önemli etmenlerden biridir. Olumlu düşünme becerisine sahip birey, bu becerisini etrafına da yansıtabilmekte bu da onun kișilerarası iletişim becerisine katkı sağlamaktadır. Üniversite öğrencileri duygusal zekâlarının iletişim becerileri ve bireysel yenilikçilik seviyeleri ile ilişkisine yönelik olarak gerçekleştirilen bir çalışmada iletişim becerileri ve duygusal zeka alt boyutlarından iyimserlik arasında pozitif yönde anlamlı bir ilişki olduğu görülmüştür (Büyükbeşe, Direkçi, Erşahan, 2017:233). Çalışmada sosyo-demografik özellikler ile ölçekler arasında ilişki olmamasına rağmen, olumlu düşünme becerisi ile kişilerarası iletişim becerisi arasında anlamlı bir ilişki olduğu saptanmıştır. Bu ilişkinin olumlu düşünme becerisi ve kişilerarası iletişim becerisi alt faktörleri (iletişim ilkeleri ve temel becerileri, kendini ifade etme, etkin dinleme ve sözel olmayan iletişim ve iletişim kurmaya isteklilik) arasında da olduğu görülmektedir(Tablo 4).

Birey her ne kadar sosyal hayat içinde olumsuz yaşam koşulları ile karşı karşıya kalsa da olumlu bakış açısı içinde bulunduğu durum ile baş etmesini kolaylaştırmakta ve hayatına devam edebilmesine olanak sağlamaktadır. Özellikle henüz iş hayatı ve hayatını idame ettirme çarkının içerisine dahil olmayan gençlerin, gelecekteki başarılarını desteklemek ve mücadele ruhunu aktif tutmalarını sağlamak adına zaman zaman eğitim çalışmaları yapılması önerilmektedir. Çalışmanın sınırlılıkları Türkçe literatürde olumlu düşünme becerisi ile kişilerarası iletişim arasında yeterli çalışmanın yer almaması ve sadece üniversite öğrencileri üzerinde yapılması gösterilebilir. Özellikle bundan sonraki çalışmalarda örneklemlerin sosyal yaşam içerisindeki bireyler üzerinde farklı eğitim seviyesinde öğrenciler üzerinde gerçekleştirilmesi ve eğitimi kapsayan deneysel çalışmaların literatüre ciddi katkılarının olacağı düşünülmektedir.

\section{Kaynakça}

Akın, A., Uysal, R., \& Akın, Ü. (2015). Olumlu Düşünme Becerileri Ölçeğinin Türkçe Formunun Geçerlik ve Güvenirliği. Akademik Bakış Uluslararası Hakemli Sosyal Bilimler Dergisi,51, 265-270.

Allen, M. Preiss R.W, Gayle, B. M. \&Burrell, N. (2001). Interpersonal Communication Research: Advances Through Meta-Analysis. Routledge.

Büyükbeşe, T., Direkçi, E. \&Erşahan, B. (2017). Üniversite Öğrencilerinin Duygusal Zekalarının İletişim Becerilerine ve Bireysel Yenilikçilik Seviyelerine Etkisi. Kahramanmaraş Sütçü İmam Üniversitesi İktisadi ve İdari Bilimler Fakültesi Dergisi, 7(2), 221-236.

Carver, C. S.,Scheier, M. F. \&Segerstrom, S. C. (2010). Optimism. Clinical Psychology Review. Vol.30. 879-889. doi: 10.1016/j.cpr.2010.01.006.

Cohen, J.,Cohen, P., West, S.G., \&Aiken, L.S. (2003). Applied Multiple Regression/Correlation Analysis for the Behaviora 1Sciences (3rd edition). Mahwah, NJ: Lawrence Earlbaum Associates.

Eğeci, İ. S. \&Gençöz, T. (2006). Factors Associated with Relationship Satisfaction: Importance of Communication Skills. Contemporary Family Therapy. 28(3). Pp. 383-391. doi:10.1007/s10591006-9010-2.

Erigüç, G., Şener, T. \& Eriş, H. (2013). İletişim Becerilerinin Değerlendirilmesi: Bir Meslek Yüksekokulu Öğrencileri Örneği. Hacettepe Sağlık İdaresi Dergisi, 16(1), 45-65.

Erozkan, A. (2013). TheEffect of Communication Skills and Interpersonal Problem Solving Skills on Social Self-Efficacy.

Educational Sciences:Theory\&Practice, 13(2), pp. 739-745.

Fernandez-Gonzalez, L.,Gonzalez-Hernandez, A. \&Trianes-Torres, M. V. (2015). Relationships Between Academic Stress, Social Support, 
Optimism-Pessimismand Self-esteem in College Students. Electronic Journal of Research in Educational Psychology, 13(1), 111-130. doi: http://dx.doi.org/10.14204/ejrep.35.14053.

Güneş, F. (2012). Öğrencilerin Düşünme Becerilerini Geliştirme. Türklük Bilimi Araştırmaları, 32(güz), 127-146.

Hazar, Ç. (2006). Kişilik ve İletişim Tipleri. Selçuk Üniversitesi İletişim Fakültesi Akademik Dergisi, 4(2). 125-140.

Korkut-Owen, F. \& Bugay, A. (2014). İletişim Becerileri Ölçeği’nin Geliştirilmesi: Geçerlilik ve Güvenilirlik Çalışması. Mersin Üniversitesi Eğitim Fakültesi Dergisi. 10(2). 51-64.

Leung, S. K.,\& Bond, M. H. (2001). Interpersonal communication and personality: Self and other perspectives. Asian Journal of Social Psychology, 4(1), 69-86. doi:10.1111/1467-839X.00076

Lyubomirsky S. \& Sin, N. (2009). Positive Affectivity. Harry T. Reis \& Susan Sprecher (Eds.). Encyclopedia of Human Relations (1265-1266). Thousand Oaks: Sage Publications. doi:710.4135/9781412958479.n409.

Nahcivan, N. (2015). Nicel Araştırma Tasarımları. Erdoğan Semra, Nahcivan Nursen \& Esin Nihal (Eds). Hemşirelikte Araștırma: Süreç, Uygulama ve Kritik içinde. (s. 87-130). İstanbul, Nobel Tıp Kitapevleri.

Naseem, Z.,\&Khalid, R. (2010). Positive Thinking in Coping with Stress and Health Outcomes: Literature Review. Journal of Research\&Reflections in Education (JRRE), 4(1), 42-61.

Nelson, D. W. (2016). Enhancing interpersonal communication: Positive mood effects. Social Behavior and Personality: an international journal, 44(9), 1535-1539. doi:10.2224/sbp.2016.44.9.1535

Pelit, E.,Karaçor, M. \& Kılıç, İ. (2018). Duygusal Zekanın İletişim Becerilerine Etkisi: Turizm Öğrencileri Üzerinde bir Araştırma. Dokuz Eylül Üniversitesi Sosyal Bilimler Enstitüsü Dergisi, 20(1), 85-107. http://dx.doi.org/10.16953/deusosbil.279686

Scheier, M. F.,\& Carver, C. S. (1992). Effects of optimism on psychological and physical well-being: Theoretical overview and empirical update. Cognitive therapy and research, 16(2), 201-228.

Scheier, M. F.,\& Carver, C. S. (1993). On The Power of Positive Thinking: The Benefits of Being Optimistic. Current Directions in Psychological Science, 2(1), 26-30. doi:10.1111/1467-8721.ep10770572

Panahi, M.,Panahi, H., \&Sobhani, H. (2016). Impacts of positive thinking skills up on happiness and academic performance of first level high school girls of Shirvan. International Academic Journal of InnovativeResearch, 3(6), 1-8.

Richard, E.,\&Diener, E. (2009). Personality and subjective well-being. InThescience of well-being(pp. 75-102). Springer, Dordrecht.

Seligman, M. E. P. \&Csikszebtmihalyi, M. (2000). Positive Psychology: An Introduction. American Psychologist. January. Vol.55(1). p. 5-14. doi: 10.1037//0003-066X.55.1.5.

Segrin, C. and Flora, J. (2000), Poor social skillsare a vulnerability factor in the development of psychosocial problems. Human Communication Research, 26: 489-514. doi:10.1111/j.14682958.2000.tb00766.x

Segrin, C. \& Taylor, M., (2007). Positive Interpersonal Relationships Mediate The Association Between Social Skills and Psychological Well-Being. Personality and Individual Differences, 43, 637-646. doi:10.1016/j.paid.2007.01.017

Shabani, M.,Pour, S. H., Morovat, Q. \&Khaledian, M. (2016). TheImpact of PositiveSkills Training andPositiveThinking OrganizationalCommitment. WSN 42, 245-255.

Shokhmgar, Z. (2016). Effectiveness of Positive Thinking Skills into Team Approach to Mental Healthand Self-esteem of Stundents Torbat-e Jam city. Electronic J Biol. Vol.12(3), 208 211). http://ejbio.imedpub.com/effectivness-of-positivethinking-skills-into-team-approach-to-mental-healthand-selfesteem-of-students-torbate-jam-city.pdf.

Spitzberg, B., H. \&Dillard, J., P. (2001). InterpersonalCommunicationResearch: Advances Through Meta-Analysis. Mike Allen, Raymond W. Preiss, Barbara MaeGayle, Nancy Burrell ( eds.), SocialSkillsandCommunication (p. 89-111), London: Routledge.

Taşlıyan, M.,Hırlak, B. \&Harbalıŏlu, M. (2015). Duygusal Zeka, İletişim Becerileri ve Akademik Başarı Arasındaki İlişki: Üniversite Öğrencilerine Bir Uygulama. ASSAM Uluslararası Hakemli Dergi, 2(3), 45-58.

Tsivilskaya, E. A. \&Artemyeva, T. V. (2016). The Study of Optimism and Positive Self-Concept of Stundents. International Journal of Humanities and Cultural Studies. July, 199-205.

Yüksel, G. (2016). Sosyal Beceri Eğitiminin Üniversite Öğrencilerinin Sosyal Beceri Düzeylerine Etkisi. Türk Psikolojik Danışma ve Rehberlik Dergisi, 2(11), $\quad$ s.s. $\quad 37-47 \quad$ ISSN $1302-1$. 